\title{
Reading Wars: An Overview of the U.S. Educational Policy
}

\author{
Markus Budiraharjo \\ Sanata Dharma University
}

\section{Abstract}

Educational scholars generally agree that educational policies are inevitably regarded as one of the most contested areas in education. On the one hand, democracy requires more involvement on the part of the citizens. At the most ideal level, democratic mechanisms have been developed to allow more people to more fruitfully participate in decision making. It follows that the political mechanisms would entail better policies, which represent the voices of any people. On the other hand, politics seems to run against this ideal. Policy making is highly convoluted with economy and political tradeoffs. Drawing on debates over the phonic vs. whole-language policies in the U.S. in the past four or five decades, this paper sets to discuss the complexity of politics and language policy. A growing awareness of the complexity of politics and policy making is certainly a pressing need for those working in the area of English Education.

Keywords: reading wars, English education, policy, politics, phonic-based instruction, wholelanguage, No Child Left Behind Act.

\section{A. INTRODUCTION}

In a liberal democracy, each citizen is expected to dearly hold ideals such as freedom to choose whatever he/she wants to be and free participation in democratic practices as high values. It follows that all citizens have equal access to political participation through public and rational discourse to reach consensual agreements concerning major issues that substantively influence public life. Rather than relying on a select elite group determining the public life, the U.S. founding fathers had established a democratic system different from the British royal system and autocratic systems widely practiced in the $17^{\text {th }}$ century in Europe and other parts of the world. Horace Mann's common school reform in the 1850s was motivated to provide children tuition-free education to allow them "participate in a real-world exercise in democracy" (Baines \& Foster, 2006 , p. 226). Given its strategic role, it is unsurprising that this field has become one of the most contested areas in policymaking process. As Pearson (2004) observes, educational policies in the U.S. context have become "society's most transparent tool for educational improvement" (p. 228). Despite the rhetoric of democracy in educational field, many deplore that teachers as the largest body of the teaching profession have continually been deprived from their role in determining educational policies, either at classroom, school, district, state, or the federal level (Wilson \& Tamir, 2008; Goodman, 2008; Kincheloe, 1991; Apple, 1979; Apple, 2009). Teaching profession has been attacked for being quasi-professional (Hess, 2006). Borrowing from British anthropologists' term "audit culture", Taubman (2009) contends that today's dismal picture of education is filled with:

discourses and practices that have accelerated the standardization 
and quantification of educational experience and turned it into an education market worth of millions of dollars; the rhetoric of blame and fear and the promulgation of heroic narratives of exemplary teachers, which coupled with the widespread use of tests, render teachers and teacher educators susceptible to the language of policy and the lure of business practices to make possible teachers' psychic investment in various aspects of the transformation (p. 13).

Underlying these trends is the growing negative attitude towards teachers, a view believing that "incompetent teachers and dysfunctional teacher educators were jeopardizing the future of the nation's youth, economy, democracy, and race relations, and unless major changes were implemented the nation was headed for disaster" (p. 3).

\section{B. POLICYMAKING AND TEACHERS}

It follows that teachers are supposed to be more knowledgeable to democratic practices, policy-making procedures, and policy impacts so as to equip them with necessary tools to engage in democracy. It is noteworthy, however, that the policymaking in the U.S. contexts is a dynamically complex process. Efforts to understand the policymaking assume a serious undertaking to comprehend the political procedures and social, historical, ideological, philosophical and cultural shifts taking place for an extended period of time. Related to the policy-making process, as Blankenhorn observes, "most public policies are a combination of rational planning, incrementalism, competition among groups, elite preferences, systemic forces, public choice, political processes and institutional influences" (cited in Borden, Stone, \& Villarruel, 2004). Such incrementalism has made the U.S. political system highly resistant to change in ordinary times (Fowler, 2006). Ideological, political, economic, and sociocultural backgrounds also provide particular contexts for the policymaking. Reviewing the Federal Government policies on reading programs in the last five decades, Shannon, Edmonson, Ortega, Pitcher \& Robbins (2009) conclude the growing pessimisms among policymakers. Even research-based knowledge developed by reading scholars, for example, has been politicized in order to allow certain vested-interest groups to support Reading First Initiative to drive standardized reading practices in the classrooms (Persltein, 2008; Allington, 2009; Shannon, et al., 2009; Harrison, 2010; Pearson, 2004). NCLB is commonly viewed as the most sweeping legislation in the U.S. education history. Its coming into existence reflects highly contested policy making processes, representing "a political compromise between the political parties and factions within those parties" (Sunderman, 2006, p. 11). Even as Hess \& Petrilli (2006) note, this complex law remained to reflect "featured ideas from left, right, and center - often without reconciling their inconsistencies" (p. 19).

Educational scholars and teachers are supposed to be knowledgeable to the complexity of educational policymaking. First, research on the qualities of exemplary teachers demonstrates a high degree of resilience and skillful strategies to use a wide variety of practices to realize their ideals (Pearson, 2004). These teachers are more motivated by their moral purpose, i.e. to make a difference in the lives of their students (Fullan, 2001). 
Fullan (1999) contend that wellintentioned teachers are characterized by their abilities to nurture change forces the underlying moral, political, and intellectual powers necessary to fuel successful reform - within themselves. Thus, understanding issues related to policymaking requires sufficient knowledge about micro-level politics as teachers, as what Shannon (2007) argues:

Although the current situation in reading education seems bleak in the United States, if you examine it closely, you'll see it far from hopeless. If students, teachers, researchers, and parents become aware of the reasons for the present conditions and work together strategically, then they can develop reading programs that keep the original promises of democratic life" (p. xv).

Second, living in democracy means involving in the multi-dimensional realities, by which we engage ourselves in a rational discourse to reach a consensual agreement regarding what we could reach. Borden, Stone \& Villarruel (2004) argue that "policy is ideally created, implemented, and evaluated through an interactive and iterative process involving theory, research, professional practice, and program development and evaluation."

This paper presents a discussion on reading wars which becomes one of the most heated policy issues in the U.S. (Harrison, 2010; Pearson, 2004; Shannon, 2007; Shannon, et al., 2009; Shaker, 2008; Perlstein, 2008; Smith, 1992; K. Goodman, 1989; Y. Goodman, 1989; Allington, 2009; Chall, 1989; Coles, 2001; Eldesky, 1990).

\section{READING WARS INVOLVING A VARIETY OF BATTLEGROUNDS}

It is worth noting that reading wars are not merely dealing with what teachers should teach in the class. Reading wars represent a set of complex ideas, including different ideologies, learning theories, and different instructional preferences. Contemporary debates over reading instruction are generally drawn from the publication of the 1955 Rudolph Flesch's book Why Johnny Can't Read. This book in particular attacked the whole word approach because it did not get students into reading children's stories that did not have carefully controlled vocabularies. This book brought phonics approach to life, leading to "back to basics" movement in the 1960s and 1970s. Briefly, phonics advocates focus their efforts on the primary grades and emphasize the importance of students being able to sound out (read) words based on how they are spelled. Efforts to create teacherproof curriculum in the post-Sputnik era brought expert-developed materials through basal reading activities (Shannon, 2007). As K. Goodman (1989) chronicled, the emergence of whole language started in the late 1970s. As a grass-root movement, classroom teachers started to produce radical change in literacy education in the U.S. Reading instruction under this new banner reflected the departure from textbooks and standardized tests. In the meantime, a growing body of scientific understanding of language development, of the relationship of language, and of how the reading and writing processes develop began to be obtained. Current trends in reading instruction encompass "the whole language movement, the interactive view of reading, critical 
reading, and literature-based reading" (McNeil, 2009, p. 322). However, it is noteworthy that the most heated debate concerning current reading wars takes place in the literacy instruction through the provision of Reading First in $2001 \mathrm{No}$ Child Left Behind Act (Allington, 2009; Shannon, 2007; Shannon, et al., 2009; Pearson, 2004).

The reading wars are currently ideologically and politically charged, bringing a tendency to reduce the philosophical, ideological, and methodological debate to "either/or proposition" (Moorman, Blanton, \& McLaughlin, 1994, p. 309). Moorman, et al., (1994) further argue that such a reductionist view makes us "pulled to one side or the other of this argument, despite personal knowledge structures and beliefs that often encompass both points of view" (pp. 309-310). It is therefore important to know how to untangle the complexity of the issues, especially related to various aspects involved.

To recap, reading wars involve a set of complex ideas, representing a number of battlegrounds in ideology, epistemology, theories of learning, knowledge base to support and/or inform classroom practice, and teacher role. First, as Shannon (2007) notes, underlying the phonics approach is a conservative ideology viewing that the U.S. is under threat of liberal ideas. The conservatives and fundamentalists "assume their values are good, [thus] any differing values of others must be evil and beneath compromise" (p. 104). Therefore, their agenda is to maintain morality in public spheres. In addition, fundamentalists also hold an antiRousseauan romantic view on children. It is "a theory of innate wickedness, [which is] going back centuries ... [and which teaches us to believe that] children will resist learning; children must be instructed in a proper climate of authority and retribution" (Smith, p. 439; italics original). In contrast, a whole-language approach comes from different perspective. As Ken Goodman (1989) argues, the approach seeks to see "common strengths and universals in human learning, it expects and recognizes differences among learners in culture, value systems, experience, needs, interests and language" (p. 209). The spirit of high expectation on diverse students is another defining characteristic of whole-language. The approach values "students' understandings and attempts to practice reading [that] would vary according to dynamic cultural identities and opportunities" (Shannon, 2007, p. 85).

The second battleground is on the different research paradigms. Upon reviewing 18 peer-reviewed journal articles in the period of 1983 to 1990, Moorman, Blanton, and McLaughlin (1994) conclude that "proponents view whole language as a comprehensive philosophy, theory, perspective, and/or set of beliefs or intentions" (p. 311). Eldesky (1990) argues that wholelanguage is not an alternate methodology for language arts instruction, but it is an educational paradigm complete with theoretical, philosophical, and political assumptions. Pearson (2004) notes that "[M]uch of the research that undergirds whole language comes from this more qualitative, more interpretive, more critical tradition. Thus, the credibility of this type of research increased in concert with the influence of whole language as a curricular movement" (p. 225). Shannon (2007) asserts that the knowledge base developed by whole language advocates was from "a variety of academic fields beyond psychology - linguistics, 
psychologists, sociology, anthropology, philosophy, child and curricular studies, composition, literary theory, and semiotics" (Shannon, 2007, p. 85). In contrast, research support for phonics approach, in Smith's (1992) observation, relied on "mechanistic approach to learning. Word identification rather than comprehension is usually the focus. Reading is seen as decoding symbols into sounds rather than as unlocking meaning" (p. 436). A case in point, Chall (1989) describes "a stronger phonics approach (code emphasis) for beginning reading tends to result in higher word recognition scores early in grade 1 than does a look-say or a weaker phonics emphasis" (p. 524). Using best-evidence synthesis for the purpose of quantification of outcomes as effect sizes, Slavin \& Cheung's (2005) investigation of 17 studies of bilingual programs is an example of a more recent revival of the positivist tradition.

The third battleground is related to instructional matters, which cover two issues, i.e. the nature of classroom activities and types of learning. First, classroom activities in phonics approach, as Moorman, Blanton, \& McLaughlin (1994) observe, are highly inauthentic, because children focus on a set of activities confined to "the worksheets, basal reader stories and related activities, spelling exercises, and other skill-based activities" (p. 315). In contrast, the wholelanguage classroom is more likely to work in authentic activities, in which "student initiated and reflect "real-world" tasks" (p. 315), such as reading trade books and newspapers, using reference materials not necessarily written for schools use, receiving spelling and punctuation instruction as it is appropriate to the piece of writing they are working on. Underlying the authentic classroom activities is a belief on the nature of reading comprehension as personal construction/interpretation. Whole language proponents believe that "there is no meaning for a text until readers construct it for themselves ... [thus], all comprehension is, by very nature, a form of interpretation" (Pearson, 1989, p. 234).

Second, Smith (1992) categorizes learning into two types, i.e. official and informal. In the official learning perspective, "[L]earning is usually difficult and takes place sporadically, in small amounts, as a result of solitary individual effort, and when properly organized and rewarded" (p. 432). This is what happens in a classroom using a phonics approach. In the informal learning perspective, "[L]earning is continuous, spontaneous, and effortless, requiring no particular attention, conscious motivation, or specific reinforcement; learning occurs in all kinds of situations and is not subject to forgetting" (p. 432). This is what happens in a whole-language classroom. Thus, instead of provided a prescribed set of strategies or methods, "whole language appears to establish a set of instructional principles which its proponents would like to see guide the practitioner during teaching" (Moorman, Blanton, \& McLaughlin, 1994, p. 311).

\section{THE DEMISE OF WHOLE-LANGUAGE AND REIGNING ONE-BEST SYSTEM}

The whole-language approach flourished for two decades in the 1980s and 1990s. Entering the new millennium, the approach was heavily battered. There is no single explanation for its demise. Pearson's (2004) analysis on the political forces in reading instruction reveals that both internally and externally, wholelanguage approach is problematic. There are three internal factors leading to the 
demise of this approach, i.e. unintended curricular casualties, questionable applications of whole language and growth of balanced literacy as a mediating force in the debate. Four casualties from the whole-language movement include skills instruction, strategy instruction, an emphasis on text structure, and reading in the content areas. One example of questionable applications is a naïve enthusiasm among many teachers adopting the approach. As Pearson (2004) notes "Many schools, teachers, and institutions appropriated the whole-language label without honoring its fundamental principles of authenticity, integration, and empowerment" (p. 223).

Externally, Pearson

identifies three factors, i.e., (1) a paradigm shift in the ideology of reading research, (2) increasing politicization of the reading research and policy agenda increasing pressure for educators of all stripes, especially reading educators, to produce measurable results, and (3) and loss of the moral high ground. The revival of positivist research paradigm used by the National Reading Panel and the National Institute for Child Health and Human Development in the mid-1990 received sympathetic ears from policymakers, especially in "phonemic awareness and phonics instruction" (Pearson, 2004, p. 225). Politicization takes place, as Pearson (2004) notes, when policy makers "like to shroud mandates and initiatives in the rhetoric of science, and sometimes that practice results in strained, if not indefensible, extrapolations from research" (p. 229). There is a growing suspicion on the role played by teachers who may induce a selfserving teacher ideology, "suggest[ing] that the broad base of privilege accorded to teachers may come at the expense of students and their parents" (Pearson, 2004, p. 232).

The demise of whole-language approach led to the reigning of phonics instruction, or in Shannon's (2007) term "one-best system". Reading First requires states to show

how the State educational agency will assist local educational agencies in identifying instructional materials, programs, strategies, and approaches, based on scientifically based reading research, including early intervention and reading remediation materials, programs, and approaches. (NCLB, 2001, p. 123).

NCLB approach is grounded in the findings of the congressionally mandated report of the National Reading Panel (NRP) issued in 2000. Reading scholars quickly found a number of limitations on the NRP research. Garan (2001) and Coles (2001) contended that the research procedure used was questionable. A variety of important instructional issues, such as the relationship of writing and reading, interconnections of emotions and literacy learning, meaning-emphasis instruction, or approaches for responding to children's individual literacy needs were excluded. Joanne Yatvin (2000), the only member of the panel having taught beginning reading in a classroom, underscored the self-serving ideology attitude among the researchers in the panel. In brief, NCLB sets out to prescribe a single literacy instruction due to its perceived effectiveness despite its questionable validity claim. As McNeil (2009) warns, there is a serious limitation to the effectiveness studies, since "they have ignored achievement in important areas - creativity, desire for further learning, ability to deal with uncertainty" 
(p. 219). It is sad, as Meyer (2003) argues, that scripted phonics moves away from culturally relevant pedagogy. Diamond's (2007) study on high-stakes testing and policy underscores the increasing alignment in contents, but not in pedagogy - which is known to be more influential in making a difference in students' life.

\section{E. CONCLUSION AND IMPLICATIONS}

This paper presents a discussion on the reading wars in the U.S. by briefly discussing its history and ideological, epistemological, and instructional issues reflected in two opposing reading approaches, i.e. whole-language vs. phonics. It can be concluded it is politics, not good purpose of well-intentioned teachers, that define what and how to teach literacy among children nowadays. Politics is messy, but that is how democracy is made up. Living in democracy requires us to be more prepared to engage in democratic processes. I would agree to Costa \& Kallick (2010) who suggest that, as teachers, we learn to change our mental models, which requires "openmindedness, flexibility, patience, and courage" (p. 211), in today's accountability era.

Although the topic of the reading wars discussed in this paper represents a brief U.S. historical overview, it serves a powerful tool to investigate the complexity of language policy making and the role of English teachers in other countries as well. Reading wars are in fact a localized policy related to how reading skills for young children are taught. It does not mean that it has no significance to English education in general. I would argue that this paper has at least two implications for English teachers in general. First, pedagogy or education for young people can never be simplified into a matter of technicalities. Teaching scholars have argued that pedagogy is all about how humans live, interact, nurture, engage, and support the growth of humanity. Teaching and learning inevitably reflect our own worldviews, what values to struggle for, and how we eventually can make a difference in the life of each student in our class, no matter who they are. It should not end in a mere rhetoric. It should be enacted in the life of a teacher. This can only be materialized in the interactions with students on a dayto-day basis. Parker Palmer (1998) warns the tendency of viewing teaching as merely methodological. Good teachers, as Palmer (1998) argues, are those who demonstrate the undivided self-identity, and who are able to explore many possibilities, not get confined to limitations. This philosophical underpinning is believed to be continually energizing teachers in the face of daunting challenges in their profession.

Second, while teachers are by nature the true decision makers in the class, they are very likely to be under scrutiny of other people, both in the field and out of the field. They are expected to be more knowledgeable to various kinds of changes and expectations from related parties. Student parents increasingly play a more influential role in today's schools. In today's politics, they are gaining an increasing stature in school issues. Teachers are expected to be more skillful at dealing with parents and their expressed expectations. In addition, teachers are also under influence of formal authorities. In a more directive, top-down culture like in Indonesia, educational policies at times are no more than added accessories. A case in point, government agencies often require paperbased compliance rather than substancebased quality in school curriculum. 
Private schools in general seem to share commonalities in the face of such formal authorities: they feel vulnerable with this government agency's strict requirements. Submissive compliance seems to be the most reasonable action among weak private schools. In reality, this is obvious with the phenomenon of two types of curricula in many schools, i.e. the formally signed curriculum, and factually implemented one. The formally signed one is written in accordance to the format and requirements set by the authority. Once agreed and signed, it is quickly shelved. It never becomes a lived curriculum. The factually implemented one seems to vary across a wide range of teachers, depending on their moral purpose, learning capacities, school contexts, and their past experiences. At this point, it is safe to say that teachers with exemplary attitudes (like hardworking, proactive, engaging, openminded, skillful at authentic listening, persevere, persistent, and other related qualities) are more likely to be significant for the lives of our their students.

\section{REFERENCES}

Allington, R.L. (2009). Literacy policies that are needed thinking beyond "No Child Left Behind." In J.V. Hoffman \& Y. Goodman (Eds.), Changing literacies for changing times: An historical perspective (pp. 266-280). NY: Routledge.

Apple, M. (1979). Curriculum and reproduction. Curriculum Inquiry, 9 (3), 231-252.

Apple, W. (2009). Is there a place for education in social transformation? In H.S. Shapiro (Ed.), Education and hope in troubled times: Vision of change for our children's world (pp. 29-46). New York: Routledge.

Baines, L., \& Foster, H. (2006). A school for the common good. Educational Horizons, 84(4), 221-228.

Borden, L.M., Stone, M., \& Villarruel, F.A. (2004). Public policy and human development. Encyclopedia of Applied Developmental Science. SAGE Publications. Retrieved June 29, 2011 from http://www.sageereference.com/view/applieddevs cience/n345.xml.

Chall, J.S. (1989). "Learning to read: The great debate" 20 years later: A response to 'Debunking the great phonics myth.' The Phi Delta Kappan, 70(7), 521-538.

Coles, G. (2001). Reading to read "scientifically". Rethinking Schools Online, 15(4). Retrieved October 8, 2011 from http://www.rethinking schools.org/archive/15_04/Read1 54.shtml

Costa, A.L. \& Kallick, B. (2010). Getting used to: Rethinking curriculum for the 21st century. In H.H. Jacobs, Curriculum 21: Essential education for a changing world (pp. 210226). Alexandria, VA: ASCD

Diamond, J.B. (2007). Where the rubber meets the road: Rethinking the connection between high-stakes testing and classroom instruction. Sociology of Education, 80(4), 285313.

Eldesky, C. (1990). Whose agenda is this anyway? A response to McKenna, 
Robinson, and Miller. Educational Researcher, 19(8), 7-11.

Fowler, F.C. (2006). Struggling with theory: A beginning scholar's experience with Mazzoni's arena models. In V.A. Anfara \& N.T. Mertz (Eds.) Theoretical frameworks in qualitative research (pp. 39-58). Thousand Oaks, CA: Sage Publication.

Fullan, M. (1999). Change forces: The sequel. Philadelphia: Falmer Press.

Fullan, M. (2001). Leading in a culture of change. San Francisco: Jossey-Bass. Garan, E.M. (2001). Beyond the smoke and mirrors: A critique of the National Reading Panel Report on phonics. Phi Delta Kappan, 500506.

Goodman, K.S. (1989). Whole-language research: Foundations and development. The Elementary School Journal, 90(2), 207-221.

Goodman, Y.M. (1989). Roots of the whole-language movement. The Elementary School Journal, 90(2), 113-127.

Harrison, C. (2010). Why do policymakers find the 'simple view of reading' so attractive, and why do I find it so morally repugnant? In K. Hall, U. Goswami, C. Harrison, \& J.S. Soler (Eds.), Interdisciplinary perspectives on learning to read: Cognition, culture and pedagogy (pp. 207-218). New York: Routledge.

Hess, F. (2006). Tough love for schools: Essays on competition, accountability and excellence.
Washington, DC: American Enterprise Institute.

Hess, F.M., \& Petrilli, M.J. (2006). No Child Left Behind Primer. New York: Peter Lang.

Kincheloe, J. (1991). Teachers as researchers: Qualitative inquiry as a path to empowerment. Bristol, PA: The Falmer Press, Taylor \& Francis Inc.

McNeil, J.D. (2009). Contemporary curriculum: In thought and action (6 $6^{\text {th }}$ Ed.). Hoboken, NJ: John Wiley \& Sons, Inc.

Meyer, R.J. (2003). Captives of the script killing us softly with phonics: A critical analysis demonstrates that scripted phonics programs hold students and teachers as curriculum hostages. Rethinking Schools Online, 17(4). Retrieved October 8, 2011 from http://www.rethinkingschools.org /archive/17_04/capt174.shtml

Moorman, G.B., Blanton, W.E., \& McLaughlin, T. (1994). The rhetoric of whole language. Reading Research Quarterly, 29(4), 308-329.

National Reading Panel. (2000). Teaching children to read: An evidence-based assessment of the scientific research literature on reading and its implications for reading instructions, reports of the subgroups. Rockville, MD: National Institute of Child Health and Human Development. Retrieved September 20, 2011 from http://www.nichd.nih.gov/publica 
tions/nrp/upload/report.pdf

No Child Left Behind Act of 2001, Title I: Improving the Academic Achievement of the Disadvantaged. (2001). Washington DC: National Clearinghouse for Bilingual Education, George Washington University.

Palmer, P. J. (1998). The courage to teach. San Francisco: Jossey-Bass.

Pearson, P.D. (1989). Reading the wholelanguage movement. The Elementary School Journal, 90(2), 230-241.

Pearson, P. D. (2004). The reading wars. Educational Policy,18(1), 216-252.

Perlstein, L. (2008). Tested: One American school struggles to make the grade. New York: Holt.

Shaker, P. (2008). Education, policy and politics. Encyclopedia of Social Problems. Sage Publications. Retrieved June 29, 2011 from $<$ http://www.sageereference.com/view/socialproble ms/n170.xml $>$.

Shannon, P. (2007). Reading against democracy: The broken promises of reading instruction. Portsmouth: Heinemann.

Shannon, P., Edmonson, J., Ortega, L., Pitcher, S., \& Robbins, C. (2009). Fifty years of Federal Government involvement in reading education. In J.V. Hoffman \& Y. Goodman (Eds.), Changing literacies for changing times: An historical perspective (pp. 251-265). NY:
Routledge.

Slavin, R.E., \& Cheung, A. (2005). A synthesis of research on language of reading instruction for English language learners. Review of Educational Research, 75(2), 247284.

Smith, F. (1992). Learning to read: The never-ending debate. The Phi Delta Kappan, 73(6), 432-435, 438-441.

Sunderman, G. L. (2006). The unraveling of No Child Left Behind: How negotiated changes transform the law. Cambridge, MA: The Civil Rights Project at Harvard University.

Taubman, P.M. (2009). Teaching by numbers: Deconstructing the discourse of standards and accountability in education. New York: Taylor and Francis.

Wilson, S.M., \& Tamir, E. (2008). The evolving field of teacher education: How understanding challenge(r)s might improve the preparation of teachers. In M. Cochran-Smith, S. Feinman-Nemser, D.J. McIntyre, \& K. Demers (Eds.), Handbook of research on teacher education (3rd ed. pp. 908-935). New York: Association of Teacher Education.

Yatvin, L. (2000). Minority view. In National Reading Panel, Teaching children to read: An evidence-based assessment of the scientific research literature on reading and its implications for reading instruction, reports of the subgroups. Rockville, MD: National Institute of Child Health and Human Development. Retrieved 
September 20, 2011 from

http://www.nichd.nih.gov/publica tions/nrp/upload/report.pdf 